\title{
Analisis Minat Muzakki Membayar Zakat di Badan Amil Zakat Nasional (Baznas) Kota Semarang
}

\author{
Rosida Dwi Ayuningtyas* dan Risti Lia Sari \\ Jurusan Ekonomi Islam, Fakultas Ekonomi, Universitas Wahid Hasyim \\ *Email: rosida@unwahas.ac.id
}

\begin{abstract}
The purpose of this study was to analyze the interest of muzakki paying zakat in the Semarang baznas. The research method used is qualitative quantitative by means of distributing questionnaires. The sample used was 50 respondents. The results of this study resulted that from the independent variables (service quality, religiosity and accountability) affecting the interest of muzakki to pay zakat in Baznas Semarang only 69\% of service quality, while for religiosity and accountability there was no partial effect on the interest of muzakki paying zakat in the baznas Semarang city. For the determination value of $41 \%$ which means that the independent variable variation model is only able to provide the information needed to predict the interest in paying zakat in the city of Semarang baznas by $41 \%$.
\end{abstract}

Keywords :Accountability, Baznas, Interest of Muzakki Paying Zakat, Religiosity, Service Quality

\section{PENDAHULUAN}

Badan Amil Zakat Nasional (Baznas) (2015) mencatat potensi zakat nasional sebesar Rp 217 triliun, sementara penerimaan zakat pada tahun 2014 mencapai Rp3,8 triliun. Di tahun 2015 Baznas menargetkan penerimaan zakat sebesar Rp 4,6 triliun. meski tingkat penerimaan zakat meningkat dari tahun ke tahun sebesar 15 persen, namun jumlah penerimaan zakat secara nasional masih jauh dari potensi zakat yang ada. Fakta ini menyiratkan bahwa zakat memiliki potensi besar dan dapat berkontribusi dalam mengurangi kemiskinan. Data zakat, infaq, dan sedekah di Indonesia menunjukkan bahwa terdapat kenaikan jumlah penghimpunan zakat dari tahun 2002 hingga 2015 (Badan Amil Zakat Nasional, 2016).

Tabel 1. Jumlah Penghimpun ZIS di Indonesia tahun 2002-2015

\begin{tabular}{|l|l|l|l|l|}
\hline Tahun & $\begin{array}{l}\text { Rupiah } \\
\text { (Milliar) }\end{array}$ & $\begin{array}{l}\text { USD } \\
\text { (Juta) }\end{array}$ & $\begin{array}{l}\text { Pertumbuhan } \\
(\%)\end{array}$ & $\begin{array}{l}\text { Pertumbuhan } \\
\text { GDP (\%) }\end{array}$ \\
\hline 2002 & 68.39 & 4.98 & - & 3.7 \\
\hline 2003 & 85.28 & 6.21 & 24.70 & 4.1 \\
\hline 2004 & 150.09 & 10.92 & 76.00 & 5.1 \\
\hline 2005 & 295.52 & 21.51 & 96.90 & 5.7 \\
\hline 2006 & 373.17 & 27.16 & 26.28 & 5.5 \\
\hline 2007 & 740 & 53.86 & 98.30 & 6.3 \\
\hline 2008 & 920 & 66.96 & 24.32 & 6.2 \\
\hline 2009 & 1200 & 87.34 & 30.43 & 4.9 \\
\hline 2010 & 1500 & 109.17 & 25.00 & 6.1 \\
\hline 2011 & 1729 & 125.84 & 15.30 & 6.5 \\
\hline 2012 & 2200 & 160.12 & 27.24 & 6.23 \\
\hline 2013 & 2700 & 196.51 & 22.73 & 5.78 \\
\hline 2014 & 3300 & 240.17 & 22.22 & 5.02 \\
\hline 2015 & 3700 & 269.29 & 21.21 & 4.79 \\
\hline \multicolumn{5}{|l}{ Sumber: Badan Amil Zakat Nasional (2016) } \\
\hline
\end{tabular}

Berdasarkan Tabel 1, dapat dilihat bahwa penghimpunan dana ZIS mengalami peningkatan sebesar 5310.15 persen dalam kurun waktu 13 tahun. Jika diperhatikan pada tahun 2006 negara Indonesia mengalami bencana alam secara berturut-turut seperti bencana alam tsunami di Aceh dan 
gempa Bumi di Yogyakarta, dimana diprediksi penghimpunan zakat menurun akibat bencana tersebut, tetapi justru kenyataanya yang terjadi adalah penghimpunan ZIS mengalami kenaikan hampir 100 persen dari 295.52 milliar menjadi 740 milliar. Jika di rata-rata dari tahun 2002 sampai tahun 2015 pertumbuhan penghimpunan ZIS mengalami kenaikan sebesar 39.28 persen. Hal tersebut mengindikasikan bahwa terdapat peningkatan kesadaran atau minat masyarakat muslim untuk membayar zakat melalui lembaga-lembaga pengelola zakat. Tren pertumbuhan tersebut juga mengindikasikan adanya peningkatan kepercayaan masyarakat terhadap kinerja lembaga pengelola zakat baik BAZNAS maupun LAZ.

Jika memperhatikan dari data diatas, ada hal penting yang ditunjukkan oleh tabel 1 dimana pertumbuhan zakat jauh lebih tinggi dibandingkan pertumbuhan GDP dengan rata-rata kenaikan sebesar 37.34 persen sedangkan pertumbuhan GDP hanya 5.4 persen, padahal GDP merupakan tolak ukur pertumbuhan ekonomi nasional. Pada tahun 2009 terjadi penurunan pertumbuhan GDP akibat krisis keuangan global sebesar 79\% sedangkan pada tahun yang sama justru pertumbuhan zakat mengalami peningkatan sebesar $80 \%$. Dari data diatas dapat disimpulkan bahwa pertumbuhan zakat tidak terlalu dipengaruhi oleh krisis global sehingga zakat merupakan salah satu alat yang dapat digunakan untuk mengurangi kemiskinan dan pengganguran dimana kedua permasalahan tersebut yang menjadi persoalan utama bagi seluruh negara khususnya Indonesia.

Di Indonesia, pengolahan zakat berdasarkan pada Undang-undang nomor 23 tahun 2011 tentang pengelolaan zakat dengan keputusan Menteri Agama nomor 581 tahun 1999 tentang pelaksanaan undang-undang nomor 23 tahun 2011. Pada hakikatnya berzakat bukan hanya bermanfaat bagi para mustahiq tetapi bermanfaat juga bagi muzakki. Orang yang mengeluarkan zakat (Muzakki) berarti ia telah mensucikan diri, jiwa dan hartanya. Ia telah membersihkan dirinya dari sifat penyakit kikir (bakhil) dan membersihkan hartanya dari hak orang lain yang ada dalam hartanya. Dilihat dari satu segi, orang yang mengeluarkan zakat berarti hartanya berkurang, tetapi dilihat dari sudut pandangan Islam, harta seseorang akan semakin bertambah, semakin berkah dan pahalanya bertambah - dilipat gandakan (Ar-Rum: 39). Harta bertambah karena mendapat ridha dari Allah berkat doa dari fakir miskin, anak-anak yatim dan ustahik lainnya. Zakat ibarat benteng dari penyakit dengki.

Menurut hasil penelitian Nusantara (2010) pendapatan, pengalaman bersedekah dan nilainilai religius berpengaruh secara signifikan terhadap kesejehateraan muzakki yang diproksi melalui pengeluaran konsumsi bersedekah, sedangkan umur, status perkawinan, etnis, pendidikan dan kesehatan tidak berpengaruh secara signifikan. Dari ketiga faktor tersebut, pendapatan adalah faktor utama yang mempengaruhi kesejahteraan muzakki yang diproksi melalui pengeluaran konsumsi sedekah.

Sedangkan berbeda menurut hasil penelitian Asdiansyuri (2016) yang menyatakan bahwa status perkawinan, pendidikan, pendapatan dan nilai-nilai religius berpengaruh terhadap pengeluaran zakat. Jika melihat dari hasil penelitian diatas dapat disimpulkan bahwa nilai-nilai religius dan pendapatan lebih dominan berpengaruh terhadap seseorang mengeluarkan zakat (muzakki).

Penilaian muzakki terhadap lembaga amil zakat begitu beragam, sesuai dengan persepsi dan pengalaman masing-masing muzakki tidak hanya karakteristik individu, nilai-nilai religius dan pendapatan para muzakki saja melainkan kualitas pelayanan. Pelayanan yang baik yang diberikan oleh lembaga amil zakat kepada muzakki akan berdampak positif kepada tingkat kepercayaan muzakki kepada lembaga amil zakat, sehingga kesadaran membayar zakat akan terus bertambah.

Menurut Ahmad dan Mohamad (2005) faktor penyebab tidak signifaknnya realisasi zakat dengan potensi zakat yang ada yaitu, pertama, masih rendahnya pemahaman dan kesadaran umat islam tentang kewajiban membayar zakat. Kedua, rendahnya minat masyarakat untuk menyetorkan zakatnya kepada institusi pemerintah dan pengelola zakat, dikarenakan banyak sekali lembaga amil zakat yang belum sepenuhnya transparansi atau terkadang tidak memberikan informasi yang jelas kegunaan zakat yang mereka bayar,sehingga para muzakki lebih senang membayar zakatnya langsung ke para mustahiq atau yang berhak.

Transparansi dan akuntanbilitas disebuah lembaga sangat diperlukan khususnya di lembaga amil zakat dimana untuk menyakinkan para muzakki diperlukan dedikasi tinggi dan profesionalitas dalam pengelolaan dana zakat. Pelaporan hasil pengelolaan zakat ini merupakan pelaporan atas 
seluruh kegiatan yang meliputi perencanaan, pelaksanaan, penatausahaan, keuangan, pertanggungjawab, dan pengawasan keuangan pengelolaan zakat. Oleh sebab itu pengelolaan zakat harus tertib dan sesuai dengan peraturan perundang-undangan, efektif, efisien, ekonomis dan bertanggungjawab (yuliafitri dan khoiriyah, 2016).

Kota Semarang merupakan ibu kota propinsi jawa tengah dimana total jumlah penduduk sekitar 1.595.187 jiwa sampai tahun 2015, $84 \%$, merupakan penduduk dengan mayoritas beragama islam. Berdasarkan data Badan Amil Zakat kota semarang muzzaki di kota semarang hanya 90 orang sama dengan tahun 2014, dengan penghimpunan dana sebesar 1.869.978.361 juta mengalami peningkatan pada tahun 2016 muzakki bertambah sebesar 253 orang tetapi penghimpunan dananya berkurang menjadi 1462.019.500. dari data tersebut terjadi fenomena gap dimana seharusnya ketika jumlah penduduk dengan mayoritas islam bertambah maka akan mengakibatkan bertambahnya dana zakat yang dihimpun oleh amil zakat. Maka dari itu perlunya penelitian lebih lanjut terkait factor apa saja yang menyebabkan muzzaki berminat membayar zakat khususnya di Baznas Kota Semarang.

\section{KAJIAN PUSTAKA \\ Definisi Zakat}

Menurut Sayyid Sabiq dalam jurnal Islamic bussines and economic, zakat secara bahasa adalah sesuatu yang dikeluarkan manusia dari hak Allah untuk fakir. Hak harta tersebut dinamankan zakat karena darinya diharapkan barakah, mensucikan jiwa dan menumbuhkan kebajikan.

According to Ahmed (2013), while the macro-economic policy has an important role in reducing poverty, poverty can not be eliminated without uses of zakat in an effective way. There are certain conditions in which zakat make an impact to reduce poverty with the first requisite, zakat should be equipped with strong macro-economic policies that promote growth and distribute income to reduce poverty second, zakat is collected and distributed, the impact on poverty will be significant when a larger percentage from zakat used to be productive sector.

\section{Minat muzakki membayar zakat}

Menurut Lucas dan Brtitt dalam Nur'aini dan Ridla (2015), aspek-aspek terdapat dalam minat antara lain:

1. Ketertarikan (interest) yang menunjukkan adanya pemusataan perhatian dan perasaan senang

2. Keinginan (desire) ditunjukkan dengan adanya dorongan untuk ingin memiliki.

3. Keyakinan (convition) ditunjukkan dengan adanya perasaan percaya diri sendiri terhadap kualitas, kuantitas, daya guna, keuntungan dari produk yang akan dibeli.

\section{Karakteristik Individu}

Bilson (2008) mengatakan bahwa terdapat empat faktor utama yang mempengaruhi perilaku konsumen, yaitu faktor budaya, social, pribadi dan psikologis.

1. Faktor budaya, kebudayaan merupakan hal yang kompleks yang meliputi ilmu pengetahuan, kepercayaan, seni, moral, adat, kebiasaan, dan norma-norma yang berlaku pada masyarakat, zakat merupakan salah satu budaya dalam islam. Zakat merupakan karakter yang penting dalam islam yang membedakannya dari agama lain. Membayar zakat adalah ibadah wajib serta kebiasaan yang berlaku dalam islam, sehingga dalam menjalankan ibadah harus disertai ilmu pengetahuan.

2. Faktor social seperti kelompok acuan, keluarga, serta peran dan status social terdiri dari semua kelompok yang mempunyai pengaruh secara langsung atau tidak lansgung. Oleh karena itu, pengetahuan zakat diperlukan untuk meningkatkan kesadaran sosial masyarakat akan wajibnya membayarnya zakat, sehingga secara otomatis meninggikan derajadnya baik dihadapan Allah SWT maupun dihadapan manusia lainnya.

3. Faktor pribadi, keputusan seseorang untuk membayar zakat dipengaruhi oleh kesadaran yang tinggi para muzakki, pendapatan, usia, tahap siklus hidup, keadaan ekonomi, gaya hidup, serta kepribadian. 
4. Faktor psikologis, pilihan seorang muzakki dalam berzakat, dipengaruhi lagi oleh empat faktor psikologi utama, yaitu : motivasi, persepsi, pengetahuan, serta kepercayaan terhadap lembaga.

\section{Kualitas Pelayanan}

Kualitas adalah derajat yang dicapai oleh karakteristik yang inheren dalam memenuhi persyaratan. Persyaratan dalam hal ini yaitu kebutuhan atau harapan yang dinyatakan biasanya tersirat atau wajib. Sedangkan pelayanan adalah suatu aktivitas atau serangkaian aktivitas yang bersifat tidak dapat diraba yang terjadi sebagaimana akibat adanya interaksi adanya konsumen dengan karyawan atau hal-hal lain yang disediakan oleh perusahaan pemberi pelayanan yang dimaksud untuk memecahkan permsalahan konsumen atau pelanggan (Winarsih, 2005 dalam Hendrianto, 2016).

Menurut Parasuraman dan Tjiptono (2009) dalam Nur'aini dan Ridla (2015), dalam mengevaluasi jasa yang bersifat intangible, konsumen umumnya menggunakan beberapa dimensi sebagai berikut:

1. Bukti Langsung (Tangible), bukti langsung meliputi fasilitas fisik, perlengakapan, pegawai, dan saran komunikasi.

2. Kehandalan (Reliability), kehandalan yakni kemampuan memberikan pelayanan yang dijanjikan dengan segera, akurat, dan memuaskan.

3. Daya Tanggap (Responsiveness), tanggapan yaitu keinginan para staf dan karyawan untuk membantu para pelanggan dan memberikan pelayanan dengan tanggap.

4. Jaminan (Assurance) jaminan menyangkut pengetahuan, kemampuan, kesopanan, dan sifat dapat dipercaya yang dimiliki para staf, bebas dari bahaya, risiko, atau keraguan.

5. Empati (Emphaty). Empati meliputi kemudahan dalam melakukan hubungan, komunikasi yang baik, perhatian pribadi, dan memahami kebutuhan para pelanggan.

\section{Nilai-nilai Religius (Religiusitas)}

Menurut Nuttin dalam Djalaludin dorongan beragama merupakan salah satu dorongan yang bekerja dalam diri manusia sebagaimana dorongan-dorongan yang lain seperti : makan, minum, intelek, dan sebagainya. Sedangkan Menurut Glock dan Stark dalam Djamaludin, terdapat lima dimensi religiusitas yaitu :

1. Dimensi keyakinan. Dimensi ini berisikan pengharapan dimana orang religius berpegang teguh pada pandangan teologis tertentu dan mengakui kebenaran doktrin tertentu. Setiap agama mempertahankan seperangkat kepercayaan dimana para penganut diharapkan akan taat. Walaupun demikian, isi dan ruang lingkup keyakinan itu bervariasi tidak hanya diantara agama-agama, tetapi seringkali juga diantara tradisi-tradisi dalam agama yang sama.

2. Dimensi praktirk agama. Dimensi ini mencakup perilaku pemujaan, ketaatan, dan hal-hal yang menunjukkan komitmen terhadap agama yang dianutnya. Praktik-praktik keagamaan ini terdiri dari dua kelas penting yaitu ritual dan ketaatan.

3. Dimensi pengalaman. Dimensi ini berisikan dan memperhatikan fakta-fakta bahwa semua agama mengandung pengharapan tertentu, meski tidak tepat jika dikatakan bahwa sesorang yang beagama dengan baik pada suatu waktu akan mencapai pengettahuan subjektif dan langsung mengenai kenyataan terakhir (bahwa ia akan mencapai suatu kontak dengan kekuatan supranatural).

4. Dimensi pengetahuan agama. Dimensi ini mengacu kepada harapan bahwa orang-orang yang beragama paling memiliki sejumlah mengai dasar, kenyakinan, ritus, kitab sucidan tradisi.

5. Dimensi pengalaman atau konsekuensi. Dimensi ini mengacu pada identifikasi akibat-kibat keyakinan beragama, praktik, pengalaman, dan pengetahuan sesorang dari hari ke hari. Wlaupun agama banyak menggarikan bagaimana pemeluknya seharusnya berfikir dan bertindak dalam kehidupan sehari-hari, tidak sepenuhnya jelas sebatas mana konsekuensikonsekuensi agama merupakan bagian dari komitmen keagamanan atau semata-mata berasal dari agama. (Nur'aini dan Ridla, 2015). 


\section{Akuntanbilitas}

Akuntabilitas merupakan dorongan psikologi sosial yang dimiliki seseorang untuk mempertanggungajwabkan sesuatu yang telah dikerjakan kepada lingkunganya atau orang lain. Akuntanbilitas dapat menjadi tolak ukur untuk pengawas lembaga zakat dalam menilai para amil zakat dalam menyelesaikan pekerjaan-pekerjaan tersebut, dengan kata lain para amil tidak akan semena-mena dalam pengelolaan zakat sehingga sistem pengelolaan lembaga amil zakat akan rapi dan tertib administrasi yang nantinya bisa menjadi sebuah informasi untuk muzakki.

Menurut NCG (National Committee on Governance) dalam Yuliafitri dan khoiriyah (2016) prinsip akuntabilitas adalah prinsip bahwa para pengelola berkewajiban untuk membina sistem akuntansi yang efektif dalam rangka untuk menghasilkan laporan keuangan yang dapat dipercaya, selain itu akuntanbilitas juga mengandung unsur kejelasan fungsi dalam organisasi dan cara mempetanggungjawabkanya

\section{Hipotesis}

$\mathrm{H}_{1}$. Kualitas Layanan berpengaruh positif terhadap minat muzakki dalam membayar zakat di Baznas Kota semarang

$\mathrm{H}_{2}$. Nilai-nilai Religius (Religiusitas) berpengaruh positif terhadap minat muzakki dalam membayar zakat di Baznas Kota semarang

$\mathrm{H}_{3}$. Prinsip Akuntanbilitas berpengaruh positif terhadap minat muzakki dalam membayar zakat di Baznas Kota semarang

\section{METODE PENELITIAN}

Penelitian ini menggunakan bentuk penelitian kualitatif kuantitatif. Metode kualitatif yaitu metode yang didasarkan pada pengumpulan data primer melalui dua proses yaitu kuisioner dan wawancara. Pada tahap kuisioner berisikan data diri dan pendapatan muzakki, sedangkan untuk tahapan wawancara berisikan pertanyaan tentang faktor yang mempengaruhi minat muzakki dalam membayar zakat di BAZ Kota Semarang. Sedangkan metode kuantitatif adalah motede yang didasarkan pada analisis data yang diperoleh melalui tahapan metode kualitatif.

Objek penelitian ini adalah para Muzakki yang ada di BAZ kota Semarang. Ada 55 responden. Pemilihan responden menggunakan metode purposive sampling, artinya pemilihan responden dilakukan sengaja dengan pertimbangan bahwa responden merupakan masyarakat yang telah mengeluarkan zakat profesi.

Tehnik pengumpulan data yang digunakan dalam penelitian ini adalah kuisioner dan wawancara. Kuisioner dibuat dalam bentuk pilihan ganda dengan lima butir opsi jawaban untuk setiap pertanyaan serta beberapa pertanyaan terbuka. Skala pengukuran yang digunakan adalah skala pengukuran likert dimana skor 5 merupakan nilai tertinggi dan skor 1 merupakan nilai terendah.

Metode analisis yang digunakan dalam penelitian ini adalah analisi Regresi Berganda. Adapun prosedur analisis data adalah sebagai berikut:

1 Uji Validitas digunakan untuk menguji kecermatan instrument dalam mengukur pernyataan dari karakteristik individu, kualitas Layanan, Nilai-nilai religius (religiusitas) dan Akuntanbilitas dan Minat Muzakki. Uji validasi item pernyataan menggnakan SPSS versi 17 dengan tehnik corrected item total correlation, jika nilai koefisienya positif dan lebih besar dari $\mathrm{r}$ tabel produc moment, maka item tersebut dinyatakan valid.

2 Uji Reliabilitas digunakan untuk mengetahui keajekan dari kuisioner variabel karakteristik individu, kualitas layanan, nilai-nilai religius, akuntanbilitas, dan minta muzaaki. Jika reliabilitas kurang dari 0.6 adalah kurang baik, sedangkan lebih dari 0,6 adalah baik (Nur'aini dan Ridla, 2015)

3 Uji Asumsi Klasik

a. Uji Normalitas yaitu Uji signifikansi pengaruh variabel independen terhadap variabel dependen melalui uji t hanya akan valid jika residual yang kita dapatkan mempunyai distribusi normal (Widarjono, 2007). Uji normalitas dapat dilakukan dengan menggunakan uji Kolmogorov Smirnov satu arah. Pengambilan kesimpulan untuk menentukan apakah suatu data mengikuti distribusi normal atau tidak adalah dengan menilai nilai 
signifikannya. Jika signifikannya $>0,05$ maka berdistribusi normal dan sebaliknya jika signifikan $<0,05$ maka variabel tidak berdistribusi normal.

b. Uji Mulitikolineritas. Menurut Miswati (2016) uji multikolinieritas diperlukan untuk mengetahui ada tidaknya variabel independen dalam suatu model. Kemiripan antar variabel independen akan mengakibatkan korelasi yang sangat kuat. Ada atau tidaknya multikolinieritas dapat diketahui atau dilihat dari koefisien korelasi masing-masing variabel bebas. Jika VIF yang dihasilkan diantara 1-10, maka tidak terjadi multikorelasi.

c. Uji Heteroskedastisitas, Widarjono (2007) Uji heteroskedastisitas bertujuan untuk memastikan dalam model regresi terjadi kesamaan variance (homoskedastisitas) dari residual satu pengamatan ke pengamatan lain. Untuk menentukan heteroskedastisitas juga dapat menggunakan grafik scatterplot, titik-titik yang terbentuk harus menyebar secara acak, tersebar baik diatas maupun dibawah angka 0 pada sumbu $\mathrm{Y}$

Regresi linier adalah analisis statistik yang berguna untuk memodelkan hubungan matematis antara variabel dependen dan variabel independen. Dalam penelitian ini analisis regresi digunakan untuk melihat pengaruh karakteristik individu, kualitas layanan, nilai-nilai religius, dan akuntanbilitas terhadap minat muzakki dalam membayar zakat. Adapun rumus regersi berganda sebagai berikut:

$$
\begin{aligned}
& \mathrm{Yt}=\beta \mathrm{o}+\beta_{1} \mathrm{X}_{1}+\beta_{2} \mathrm{X}_{2}+\beta_{3} \mathrm{X}_{3}+\beta_{3} \mathrm{X}_{3}+\mathrm{e}_{\mathrm{i}} \\
& \text { Dimana } \mathrm{Yt}=\text { Minat Muzakki mambayar zakat } \\
& \mathrm{Bo}=\text { Konstanta } \\
& \mathrm{X} 1=\text { kualitas layanan } \\
& \mathrm{X} 2=\text { nilai-nilai religius } \\
& \mathrm{X} 3=\text { akuntanbilitas } \\
& \mathrm{e}=\text { error }
\end{aligned}
$$

Menurut Widarjono (2017) Uji parsial merupakan pengujian secara individu apakah variabel independen berpengaruh terhadap variabel dependen. Adapun syarat ketentuannya sebagai berikut:

1. Probability $T$-stastistic < taraf nyata $(\alpha)$, maka tolak $\mathrm{H}_{0}$ dan dapat disimpulkan bahwa minimal ada satu variabel independen yang mempengaruhi variabel dependennya.

2. Probability $T$-statistic $>$ taraf nyata $(\alpha)$, maka terima $\mathrm{H}_{0}$ dan disimpulkan bahwa tidak ada variabel independen yang mempengaruhi variabel dependennya.

Menurut Widarjono (2017) Uji Determinasi adalah uji untuk mengukur seberapa jauh kemampuan sebuah model dalam menerangkan variabel dependen, jika nilai $\mathrm{R}^{2}$ mendekati 1 berarti varabelvariabel independen mampu memberi informasi yang dibutuhkan untuk memprediksi variabel dependen.

\section{HASIL DAN PEMBAHASAN}

Gambaran Umum Karakteristik Muzakki
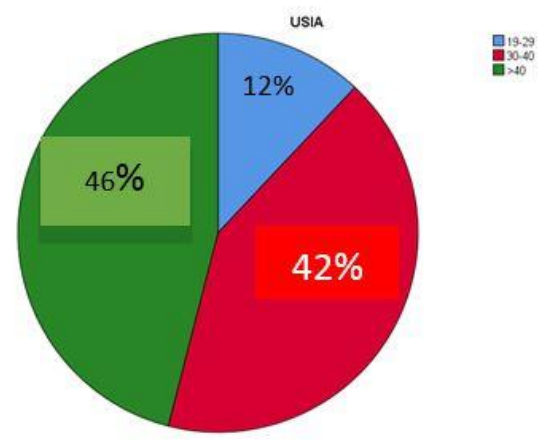

Sumber: Data diolah (2019)

Gambar 1. Usia Responden (Muzakki)

Berdasarkan hasil gambar 1 dapat dijelaskan bahwa usia responden (Muzakki) $46 \%$ memiliki usia > 40 tahun, sedangkan $42 \%$ memiliki usia 30 sampai 40 tahun, serta $12 \%$ merupakan usia 1929 tahun. 


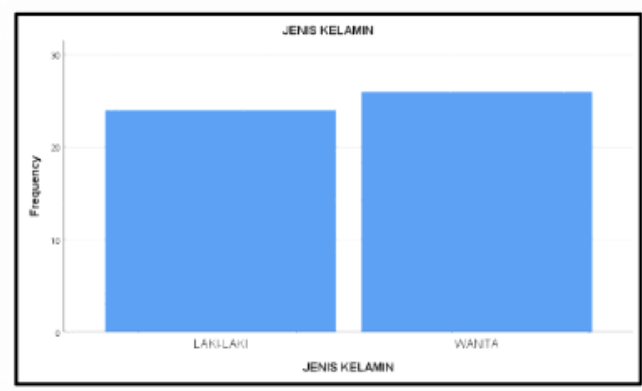

Sumber : Data diolah (2019)

Gambar 2. Jenis Kelamin Responden (Muzakki)

Berdasarkan gambar 2, dapat dijelaskan bahwa jenis kelamin respon untuk wanita lebih banyak sedikit disbanding laki-laki. Untuk wanita 52\%, sedangkan untuk laki-laki $48 \%$ dari total responden 50.

\begin{tabular}{|c|l|l|l|}
\hline \multicolumn{2}{|c|}{ Pekerjaan } & Frequency & Percent \\
\hline \multirow{3}{*}{ Valid } & PNS & 43 & 86.0 \\
\cline { 2 - 4 } & SWASTA & 7 & 14.0 \\
\cline { 2 - 4 } & Total & 50 & 100.0 \\
\hline
\end{tabular}

Sumber : Data diolah (2019)

Gambar 3. Pekerjaan Responden (Muzakki)

Berdasarkan hasil gambar 3 pekerjaan responden lebih banyak pegawai negeri yaitu sebesar $86 \%$ dibandingkan pegawai swasta yang hanya $14 \%$, hal ini dikarenakan seluruh pegawai negeri di kota semarang yang ingin membayar zakat dianjurkan membayar zakat ke baznas kota semarang, walaupun tidak menutup kemungkinan untuk swasta bisa membayar zakat di baznas kota semarang.

\begin{tabular}{|c|c|c|c|c|}
\hline \multicolumn{2}{|c|}{ Lama } & Frequency & Percent & Valid Percent \\
\hline Valid & $1-5$ & 15 & 30.0 & 30.0 \\
\cline { 2 - 5 } & $6-10$ & 22 & 44.0 & 44.0 \\
\cline { 2 - 5 } & $>10$ & 13 & 26.0 & 26.0 \\
\cline { 2 - 5 } & Total & 50 & 100.0 & 100.0 \\
\hline \multicolumn{4}{|c|}{ Sumber : data diolah (2019) }
\end{tabular}

Gambar 4. Lama menjadi Muzakki

Gambar 4 menjelaskan bahwa dari 50 muzakki, terdapat $44 \%$ responden yang telah menjadi muzakki selama 6 sampai 10 tahun, serta 30\% responden yang telah menjadi muzakki selama 1 sampai 5 tahun, sedangkan $26 \%$ responden telah menjadi muzakki > dari 10 tahun. Hal ini menandakkan bahwa semakin lama responden menjadi muzakki maka semakin tinggi pemahaman responden tentang pentingnya membayar zakat, kata lain mereka sudah paham apabila zakat merupakan harta yang wajib dikeluarkan untuk mensucikan jiwa dan harta.

Pengujian validasi tiap item pertanyaan dilakukan dengan menghitung korelasi Pearson Product Moment antara skor item dengan skor total. Dinyatakan valid apabila nilai signifikansi < 0,05 atau $5 \%$ dengan $\mathrm{df}=50-2=48(\mathrm{r}$ table $=0.2787)$ dengan uji dua sisi. Berdasarkan data tabel 2 menunjukkan bahwa semua item pertanyaan dinyatakan valid dikarenakan $\mathrm{R}$ hitung $>\mathrm{R}$ tabel (0.278) serta nilai signifikansi $<0.05$, maka semua item dinyatakan valid. 
Tabel 2. Uji Validitas

\begin{tabular}{|c|c|c|c|c|}
\hline item & R hitung & R Tabel & Sig & Valid \\
\hline X1.1 & 0.767 & 0.2787 & 0.000 & valid \\
\hline X1.2 & 0.859 & 0.2787 & 0.000 & valid \\
\hline X1.3 & 0.688 & 0.2787 & 0.000 & valid \\
\hline X1.4 & 0.763 & 0.2787 & 0.000 & valid \\
\hline X1.5 & 0.781 & 0.2787 & 0.000 & valid \\
\hline X2.1 & 0.841 & 0.2787 & 0.000 & valid \\
\hline X2.2 & 0.717 & 0.2787 & 0.000 & valid \\
\hline X2.3 & 0.788 & 0.2787 & 0.000 & valid \\
\hline X2.4 & 0.599 & 0.2787 & 0.000 & valid \\
\hline X2.5 & 0.618 & 0.2787 & 0.000 & valid \\
\hline X3.1 & 0.740 & 0.2787 & 0.000 & valid \\
\hline X3.2 & 0.774 & 0.2787 & 0.000 & valid \\
\hline X3.3 & 0.833 & 0.2787 & 0.000 & valid \\
\hline X3.4 & 0.781 & 0.2787 & 0.000 & valid \\
\hline X3.5 & 0.701 & 0.2787 & 0.000 & valid \\
\hline Y1.1 & 0.424 & 0.2787 & 0.002 & valid \\
\hline Y1.2 & 0.698 & 0.2787 & 0.000 & valid \\
\hline Y1.3 & 0.795 & 0.2787 & 0.000 & valid \\
\hline Y1.4 & 0.731 & 0.2787 & 0.000 & valid \\
\hline Y1.5 & 0.624 & 0.2787 & 0.000 & valid \\
\hline
\end{tabular}

Sumber : data diolah (2019)

Tabel 3. Uji Realibilitas

\begin{tabular}{|l|l|l|l|}
\hline Variabel & R hitung & $\begin{array}{l}\text { Alpha } \\
\text { Cronbach }\end{array}$ & Jumlah item (n) \\
\hline X1 & 0.825 & 0.60 & 5 \\
\hline X2 & 0.738 & 0.60 & 5 \\
\hline X3 & 0.823 & 0.60 & 5 \\
\hline Y & 0.667 & 0.60 & 5 \\
\hline
\end{tabular}

Sumber : data diolah (2019)

Berdasarkan hasil tabel 3 menjelaskan bahwa semua variabel baik itu dependen maupun independen memiliki nilai $r$ hitung lebih besar disbanding alpha cronbach 0.60 yaitu 0.825 (X1), $0.738(\mathrm{X} 2), 0.823(\mathrm{X} 3)$ serta $0.667(\mathrm{Y})$ maka variabel dinyatakan reliabel.

\section{Uji asumsi klasik}

Uji normalitas dapat dilakukan dengan menggunakan uji Kolmogorov Smirnov satu arah. Pengambilan kesimpulan untuk menentukan apakah suatu data mengikuti distribusi normal atau tidak adalah dengan menilai nilai signifikannya. Jika signifikannya $>0,05$ maka berdistribusi normal dan sebaliknya jika signifikan $<0,05$ maka variabel tidak berdistribusi normal. Data didalam penelitian ini menunjukkan bahwa asymp sig (2- tailed) sebesar $0.200>0.05$, maka dinyatakan data berdistibusi normal.

Dinyatakan tidak terjadi multikolinieritas, jika suatu model regresi mempunyai nilai VIF (Variance Inflation Factor) kurang dari angka 10 dan mempunyai nilai tolerance lebih dari 0.1. jika melihat hasil dari olahan data didalam penelitian ini dapat disimpulkan bahwa nilai VIF X1 sebesar 1.792 (0.558), nilai VIF X2 sebesar 1.213 (0.824) sedangkan nilai VIF X3 sebesar 1.775 (0.563). jika melihat data tersebut semua variabel terbebas dari multikolinieritas.

Uji Heteroskedastisitas

Untuk menentukan heteroskedastisitas juga dapat menggunakan grafik scatterplot, titik-titik yang terbentuk harus menyebar secara acak, tersebar baik diatas maupun dibawah angka 0 pada 
sumbu Y. berdasarkan hasil gambar 5 bahwa data tidak terjadi heteroskedastisitas, karena titik titik tersebar acak baik diatas angka 0 maupun sumbu $Y$

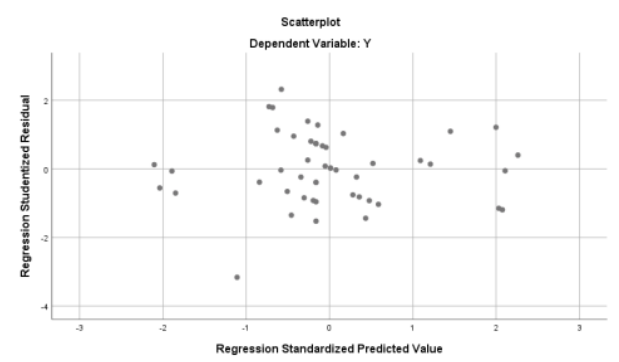

Sumber : data diolah (2019)

\section{Gambar 5. Uji Heteroskedastisitas}

\section{Uji Hipotesis}

Dalam penelitian ini analisis regresi digunakan untuk melihat pengaruh karakteristik individu, kualitas layanan, nilai-nilai religius, dan akuntanbilitas terhadap minat muzakki dalam membayar zakat. Adapun rumus regersi berganda sebagai berikut:

$\mathrm{Yt}=\beta \mathrm{o}+\beta_{1} \mathrm{X}_{1}+\beta_{2} \mathrm{X}_{2}+\beta_{3} \mathrm{X}_{3}+\beta_{3} \mathrm{X}_{3}+\mathrm{e}_{\mathrm{i}}$

Minat $(\mathrm{Y})=5.766+0.696($ Layanan $)+0.065$ (Religiusitas $)-0.115$ (Akuntanbilitas)

\begin{tabular}{|c|c|c|c|c|c|c|}
\hline & \multicolumn{6}{|c|}{$\begin{array}{c}\text { Tabel 4. Estimasi Regresi Berganda } \\
\text { Coefficients }^{\mathrm{a}}\end{array}$} \\
\hline & \multirow[b]{2}{*}{ Model } & \multicolumn{2}{|c|}{ Unstandardized Coefficients } & \multirow{2}{*}{$\begin{array}{l}\text { Standardized } \\
\text { Coefficients } \\
\text { Beta }\end{array}$} & \multirow[b]{2}{*}{$\mathrm{T}$} & \multirow[b]{2}{*}{ Sig. } \\
\hline & & B & Std. Error & & & \\
\hline \multirow[t]{4}{*}{1} & (Constant) & 5.766 & 3.370 & & 1.711 & .094 \\
\hline & $\mathrm{X} 1$ & .696 & .150 & .699 & 4.638 & .000 \\
\hline & $\mathrm{X} 2$ & .065 & .154 & .052 & .423 & .674 \\
\hline & X3 & -.115 & .139 & -.124 & -.827 & .413 \\
\hline
\end{tabular}

a. Dependent Variable: Y

Berdasarkan hasil tabel 4. Variabel independen yang mempengaruhi minat muzakki membayar zakat hanya variabel X1 (Kualitas Layanan) dengan nilai signifikansi $0.000<\alpha 0.05$ yang artinya bahwa jika kualitas layanan naik $1 \%$ maka minat muzakki membayar zakat naik sebesar 0.696 atau $69 \%$. Sedangkan untuk variabel $\times 2$ dan $\times 3$ tidak berpengaruh terhadap minat muzakki membayar zakat dikarenakan nilai sig $>\alpha 0.05$ yaitu sebesar 0.674 (x2) dan 0.413 (x3). Sedangkan nilai determinasi $\left(\mathrm{R}^{2}\right)$ didalam penelitian ini sebesar 0.418 atau $41 \%$ sedikit jauh dari $100 \%$ atau 1 dengan kata lain variasi model varabel-variabel independen mampu memberi informasi yang dibutuhkan untuk memprediksi variabel dependen hanya sebesar $41 \%$ sisanya 59\% dipengaruhi oleh variabel lain.

\section{Pengaruh Kualitas Layana terhadap Minat Muzakki membayar zakat}

Berdasarkan hasil estimasi regresi diatas bahwa kualitas layanan berpengaruh terhadap minat muzakki membayar zakat sebesar $69 \%$ yang artinya apabila kualitas layanan dinaikan sebesar $1 \%$ maka akan mengakibatkan minat muzakki membayar zakat semakin meningkat sebesar $69 \%$. Kualitas layanan yang baik akan memicu minat muzakki semakin tinggi dan sebaliknya. Menurut Saad dan Jaffri (2010) bahwa efisiensi dan kualitas pelayanan dalam mengelola zakat mempengaruhi minat seorang muslim untuk membayar zakat. sejalan dengan penelitian Saad dan Jaffri, hasil penelitian Salmawati dan Meutia Fitri (2018) kualitas layanan berpengaruh terhadap minat muzakki membayar zakat di Baitul Mal Kota Banda Aceh, sedangkan hasil penelitian 
Nuráini dan Rasyid Ridla (2015) kualitas layanan tidak mempengaruhi minat muzakki untuk menyalurkan zakat profesi di Pos Keadilan Peduli Ummat Yogyakarta.

\section{KESIMPULAN}

Berdasarkan pembahasan didalam penelitian ini, dari tiga variabel (kualitas layanan, Religiusitas dan Akuntanbilitas) yang mempengaruhi minat muzakki untuk membayar zakat di Baznas Kota Semarang hanya kualitas layanan sebesar 69\%, sedangkan untuk religiusitas dan akuntanbilitas tidak berpengaruh secara parsial terhadap minat muzakki membayar zakat di baznas kota semarang. Untuk nilai determinasi sebesar $41 \%$ yang artinya bahwa model variasi variabel independen hanya mampu memberikan informasi yang dibutuhkan untuk memprediksi minat muzakki membayar zakat di baznas kota semarang sebesar $41 \%$.

\section{DAFTAR PUSTAKA}

Ahmad dan Mohammad. (2005). Penswastaan Zakat dan Kesannya Terhadap Pembayaran Secara Formal di Malaysia. Kumpulan Kajian Ekonomi dan Kewangan Islam.

Ardiansyuri. (2016). Analisis Pengaruh Pengeluaran Zakat, Infak Dan Sedekah Terhadap Kesejahteraan Muzakki (Studi Pada Baznas Di Kabupaten Lombok Barat). International Journal of Social and Local Economic Governance (IJLEG), 2(1), 23-31.

Bilson. (2008). Panduan Riset Perilaku Konsumen. Jakarta: PT. Gramedia Pustaka Utama.

Badan Amil Zakat. (2016). Oulook Zakat Nasional 2017. Jakarta: Baznas.

Muhammad, Sani Adamu dan Ram Al Jaffri. 2010. Gelagat Kepatuhan Zakat Perniagaan, Jurnal Pengurusan 30, 49-61

Nusantara. (2010). Analisis Kesejahateraan Muzakki Berdasarkan Pengeluaran Konsumsi Sedekah (Studi di Kota Malang Provinsi Jawa Timur). Disertasi, Universitas Brawijaya.

Nuráini, Hanifah dan MR Ridla (2015). Pengaruh Kualitas Pelayanan, Citra Lembaga dan Religiusitas Terhadap Minat Muzakki untuk menyalurkan Zakat Porfesi ( Studi di Pos Keadilan Peduli Umat Yogyakarta). Jurnal Membangun profesionalisme keilmuan.

Salmawati dan Meutia Fitri. (2018). Pengaruh Tingkat Pendapatan, Religiusitas, Akuntanbilitas dan Kualitas Pelayanan Terhadap Minat Muzakki Membayar Zakat Di Bbaitul Mal Banda Aceh. Jurnal Ilmiah Mahasiswa Ekonomi Akuntansi (JIMEKA). Vol. 3, No. 1 (54-66)

Widarjono. (2007). Ekonometrika (Pengantar dan Aplikasi). Yogyakarta: Ekonisia.

Yuliafitri dan Khoiriyah. (2016). Pengaruh kepuasan muzakki, transparansi dan akuntanbilitas pada lembaga amil zakat terhadap loyalitas muzakki (studi persepsi pada LAZ Rumah Zakat),. Jurnal Ekonomi Islam, 7 ( 2, Edisi Juli- Desember), page 205-218. 